\title{
Interface of Services Sector and Economic Growth in Nigeria: An Empirical Investigation (1981-2017)
}

\author{
Aderoju Bolanle Rahmon ${ }^{1}$ and Mosobalaje Risikat Olaitan ${ }^{2}$ \\ 1.Department of Economics, School of Arts and Social Sciences, The College of Education, Lanlate, P. M. B. \\ 001. Oyo State, Nigeria \\ 2. Department of Economics, School of Arts and Social Sciences, Emmanuel Alayande College of Education, P. \\ M. B. 1010, Oyo State, Nigeria.
}

\begin{abstract}
This study empirically explored economic growth implications of services sector in Nigeria. Time series data for the period 1981 to 2017 were extracted from the Central Bank of Nigeria (CBN) Statistical Bulletins and National Bureau of Statistics (NBS). Data were analyzed using Augumented Dickey Fuller (ADF) unit root test, Phillips-Perron (PP) unit root test, Johansen Cointegration test and Ordinary Least Square (OLS) multiple regression analysis. Empirical findings from the study revealed that financial services (FINS), real estate services (REES)), utilities (UTS), professional, scientific and technical services (PSTS) and information and communication services (IACS) have statistically significant positive relationships with economic growth (RGDP) in Nigeria. A one percent increment in FINS, REES, UTS, PSTS and IACS would cause economic growth to increase by $50.57,31.76,22.58,81.79$ and 31.06 percent respectively. The results further showed that education services (EDUCS), human health and social services (HHSS) and inflation rate (INFR) have statistically significant negative correlation with economic growth. A one percent upward adjustment in EDUCS, HHSS and INFR would bring about $0.077,38.71$ and 13.61 percent reductions in economic growth. Based on the findings, government at all levels should offer tariff and tax reduction for investment projects in many services sub-sectors like hotels and restaurants, hospitals, shipping, railways, tourism, telecommunications, distribution and others; public and private policies should be directed towards the adoption of an overall reforming plan where capital and knowledge intensive services should play a prominent role in order to enhance the productivity in the services sector; and there should be creation of enabling environment for services sector to thrive by the various tiers of government through the provision of key infrastructural amenities such as uninterrupted power supply, good roads network and regular water supply. Finally, most services' subsectors, and especially distribution services should invest much more heavily in knowledge and information and communication technology within their supply chain in order to accelerate the rate of economic growth.
\end{abstract}

Keywords: Services sector, Economic growth, Ordinary least square, Unit root test, Johansen Cointegration test, Nigeria

DOI: $10.7176 / \mathrm{JPID} / 49-06$

Publication date: April $30^{\text {th }} 2019$

\section{Introduction}

Services play a central role in the economies of both advanced and developing countries. They account for over half of the real gross domestic product of all advanced economies and constitute the single largest sector in most developing countries. According to Central Bank of Nigeria Statistical Bulletin (2017), the services sector comprises road transport, rail transport and pipelines, water transport, air transport services, post and courier services, telecommunications and information services, publishing, motion pictures, sound recording, broadcasting, electricity, gas, stream and air conditioning, water supply, sewage, waste management, accommodation and food services, financial services, insurance services, real estate services, professional, scientific and technical services, administrative and support services, public administration, education, human health and social services, arts, entertainment and recreation. Several reasons are attributable to the growth of services sector in both developed and developing countries of the world. These include rapid urbanization, the expansion of the public sector and increased demand for intermediate and final consumer services. The successful growth of the primary and secondary activities in most advanced and developing economies, to a large extent, is dependent on services offered by information and communication, banking, transport, real estate, insurance, trade, commerce, entertainment, human health, administration and numerous other services categorized as tertiary activities. 
In Nigeria, many services are key inputs to all or most other businesses, for example, infrastructure services such as energy, telecommunications and transportation; financial services which facilitate transactions and provide access to finance for investment; health and education services which contribute to a healthy, welltrained workforce; and legal and accountancy services which are part of institutional framework required to underpin a healthy market economy. These services are thus a key part of the investment climate, and can have a much wider impact on overall business performance and the level of investment, and hence growth and productivity in the economy. Since its return to democracy in 1999, Nigeria has witnessed significant economic and political reforms which, coupled with increased demand for its natural resources, helped ignite unprecedented economic growth, averaging nearly 7\% between 2001 to 2011 (African Development Bank, 2011), and over 6\% up until 2014. Nevertheless, the economy has been confronted with several challenges including high level of corruption, high level of unemployment, technological backwardness, poor infrastructural development, widespread insecurity, human trafficking, drug trafficking, widespread kidnapping, overdependence on oil and others too numerous to mention. Moreover, the economic growth rate has experienced a significant downturn, falling drastically to $2.7 \%$ in 2015 due to sharp decline in oil prices from mid-2014, with the economy officially falling to recession in 2016 (World Bank, 2017). These recent developments have resulted in a renewed call by policy analysts for economic diversification away from oil, enhancing growth in the private sector and driving employment growth in a bid to stimulate and ensure sustained economic growth (Kale, 2016).

Since the contribution of the secondary industry to growth and employment is very poor in many SubSaharan African countries particularly in Nigeria, and based on the success of some developing countries such as the South Asian economies in service-led growth, the service sector has been identified as a sector with the potential to become a significant driver of sustained growth in Africa (Ghani \& O'Connell, 2014; UNCTAD 2015). In this thought, a well-functioning service sector is considered important for the overall economic performance of African economies and the welfare of its citizens. Besides, a more productive service sector also strengthens the performance of other sectors such as manufacturing (Khanna, et al. 2016). According to the Central Bank of Nigeria Statistical Bulletin (2017), the figure for services sector was \#3684.44 billion in 1981. This figure rose to \#3779.20 billion in 1985 while it stood at \#4645.60 billion in 1990. The figures for services sector in 1995 and 2000 were \#5422.77 billion and \#6709.18 billion respectively. In 2005, the figure increased astronomically to \#10624.12 billion while it amounted to \#18966.55 billion in 2010. The contribution of services sector to the economy stood at \#25374.78 billion in 2015 and declined to \#24904.37 billion in 2017. Several studies have been conducted on the impact of agricultural sector, manufacturing sector, solid minerals sector and others on economic growth and development in Nigeria. The literature on the contribution of services sector to economic growth and development in the economy is very scanty. This paper intends to fill the existing lacuna by exploring the contribution of education services, financial services, real estate services, utilities, human health and social services, information and communication services, professional, scientific and technical services on economic growth and development in Nigeria. This study seeks to provide answers to the following questions: Does services sector exert statistically significant positive contribution on economic growth in Nigeria? What are the factors militating against the contribution of services sector to economic growth in Nigeria? What policy measures should be formulated and implemented by the various tiers of government to ensure massive contribution of services sector to economic growth in Nigeria?

\section{Objectives of the Study}

The general objective of the study is to empirically examine the contribution of services sector to economic growth in Nigeria over the period 1981 and 2017. The specific objectives which this study sets out to achieve are:

-to investigate the relationships among education services, financial services, real estate services, utilities and economic growth over the studied period in Nigeria.

-to examine the impact of human health and social services, information and communication services, professional, scientific and technical services on economic growth in Nigeria within the studied period. 
- to suggest policy measures for ensuring massive or significant contribution of services sector to economic growth in Nigeria.

\section{Study Hypotheses}

The hypotheses to be verified by this study are stated in the null and alternative forms below:

1. $\mathrm{H}_{0}$ : Services sector has no statistically significant positive relationship with economic growth in Nigeria. $\mathrm{H}_{1}$ : Services sector has statistically significant positive relationship with economic growth in Nigeria

\section{Research Questions}

This study is expected to provide answers to the following questions:

1. Do financial services, education services, real estate services and utilities exert statistically significant positive relationships with economic growth in Nigeria?

2. What impact do human health and social services, information and communication services, professional, scientific and technical services have on economic growth in Nigeria?

3. What policy measures should be implemented by various tiers of government to ensure massive contribution of services sector to economic growth in Nigeria?

\section{Review of Related Literature}

The literature investigating the contribution of services sector to economic growth in Africa is still relatively scanty. It is worth mentioning that the impact of services sector on economic growth has started receiving attention from scholars employing different case studies to demonstrate the increasing role of services in African economies. Ellis et al. (2017) examined the role that different subsectors of formal and informal services have played in Tanzania's growth. The authors argued that subsectors such as business and transportation services exhibit higher productivity and improve the environment for other firms to operate Tanzania's economy. Bhorat et al. (2016) examined the impact of services sector on economic growth in South Africa. The results of the study demonstrated that an ongoing decline in industry has been coupled with rapid growth across a range of services sector. A recognition of the potential offered by the services sector was also shown to be recognized in the policy arena in South Africa, as evident in the targeting of the business sector in South Africa's National Development Plan. Khanna et al. (2016) investigated the contribution of services sector to economic growth of Kenya. The study found that Kenya services export increased more than doubled from $\$ 1.9$ billion in 2005 to $\$ 4.9$ billion in 2012, and thereby experienced more dynamic growth than goods export. As a result of this, the authors contend that Kenya has rapidly asserted itself as a regional services hub.

Madhav (2016) empirically examined the impact of expanding services sector on economic growth of Nepal. The study employed the Autoregressive Distributed Lag (ARDL) approach to cointegration on the time series data of the period 1975 to 2016. Empirical findings revealed that services sector exerts a statistically significant positive relationship with economic growth of Nepal during the studied period. Results also showed services sector enhancing role of education and export trade of the country. The study concluded that services sector of the country has a great potential to contribute to economic growth and that manufacturing sector should be revived from its current low level. Raber and Faiz (2016) examined the main factors responsible for growth in productivity in the Palestian service sector and discussed the impact of intra-sectoral heterogeneity on the growth of productivity using a panel data provided by the Palestian Central Bureau of Statistics. The results revealed that capital intensive service sectors have a high influence on the growth of labour productivity in service sector. The authors recommended the adoption of new policies based on the use of information and communication technology (ICT) by service firms or public institutions in order to increase the contribution of service sector to economic growth. In assessing the overall contribution of services to India's growth, Mukherjee (2015) showed that the significant contribution of services sector to GDP, GDP growth, trade and FDI inflows, makes it the fastest growing sector in India. Moreover, the share of services sector in India's total trade currently exceeds the global average, placing it among the top 10 WTO member countries in services export and imports. Wu (2015) showed that despite lagging when compared with economies at similar stage of development, in isolating, 
China's services have lately emerged as the dominant contributor to economic growth and job creation. Yusuf (2015) contended that the profitability and competitiveness of firm is becoming closely associated to the quality, and innovativeness of services, and that the bundling of services with industry is key to making high returns over the long-run.

Abdulkarim (2014) empirically investigated the role of the services sector in the economic growth of Saudi Arabia during the period of 1969 to 2012. Systematic econometric techniques were employed to investigate the causal relationship and the magnitude of impact between the services sector and economic growth using annual data . Empirical findings revealed that there exists a long term stable dynamic relationship between the services sector and economic growth. The services sector plays an important role in economic growth, since every one percent increase in services sector output will promote 0.93 percent economic growth. The granger causality test shows that two-way granger causality exists between the service sector and economic growth. The study recommended that the policy makers should formulate a long term services development strategy that enhances the Saudi industrial structure away from current oil-revenue dependency structure. Ghani and Connell (2014) argued that services can be dynamic and can be a growth escalator, as services are now contributing more than manufacturing in growth and jobs in both low and high-income countries. Eichengreen and Gupta (2013) analyzed panel data and regressed the percentage share of services in the GDP upon four powers of log of per capita income (linear, squared, cube and quadratic) interaction terms, trade share, share of urban population and age dependency ratio. Empirical results showed the growth of traditional services in countries with relatively low level of incomes and the increase in modern services in countries with relatively high level of per capital income.

Ghani (2010) in a cross country growth regression found that both services and manufacturing sector are important to GDP growth but that the services sector has a stronger correlation with the overall growth than the manufacturing sector. Arnold et al. (2010) discovered India covering banking, insurance, telecommunication and transport improved their services policies which leads to improvement in manufacturing productivity, this is another way that service sector has taken part in improving economic efficiency, therefore service sector plays important role in the growth of economy directly and also indirectly. Miroudot et al. (2010) showed that productivity growth related with those service sectors which were more open to international competition. Arnold et al. (2008) suggested that finance, transport and telecommunication are the backbone of service sector which allowed business and open international competition. Ghani (2009) showed that in Bangladesh, India and Sri Lanka, modern services grew at an average rate of over 12\% per annum between 2000 and 2006. Correspondingly, the growth rates in traditional services for these countries were between 10,8 and $4 \%$ respectively. Bosworth and Maertens (2009) showed how absolute levels of labour productivity are highest in the services sector in South Asian countries. Moreover, in the post-2000 era, labour productivity growth for South Asia has been higher in services than in manufacturing, with services contributing more to employment and thus, poverty reduction for many developing countries. Baharom (2009) examined the causal relationship between services sector and economic growth for India and China. Empirical findings showed a unidirectional causal relationship running from economic growth to service industry for India and an opposite unidirectional causality flowing from services sector to economic growth for China. Linden and

Hoekman and Eschenbach (2005) found that there was positive relationship between the service sector and economic growth, as economic growth rose with service sector growth. Ghani and Clemes (2002) investigated the determinants of per capita economic growth in the group of ASEAN economies using panel data from 1965 to 1994 with particular attention paid to the contribution of services to the growth of real GDP per capita. In the regression of the service sector growth, the prime regressors were growth of real output, growth of manufacturing sector, growth in real exports, growth in imports, and government expenditure on infrastructure. Estimation results of a structural per capita growth equation revealed that growth of services exerts a statistically significant positive on the overall economic growth in the panel of countries. In addition, the results substantiate a strong positive influence of growth in manufacturing and government spending on service sector growth. Moreover, services also showed a spillover effect on manufacturing. Kongsamut, Rebelo and Xie (2001) analyzed the association among economic growth, share of agriculture, manufacturing and services for Sri Lanka. The study found the share of services in output to be linear in per capita income. Economic Council of 
Canada (1991) reported that the supremacy of service sector accounts to two thirds of employment and output in developed countries. In addition, the association of service sector and economic growth depends on the size of sector and its productivity in the economy.

Glasmeier and Howland (1993) maintained that the services sector is increasingly viewed as the key to economic growth in most economies of the world, with two opposing schools of thought on the relationship. The first assumes that the services sector can aid economic growth and the second disputes the independence of the services sector and does not see it as a replacement for the traditional sectors such as agriculture, mining and manufacturing. The study concluded that evidence of a positive existing causal relationship between the services sector and economic growth is uncertain. Mansell (1985) suggested that service sector was based on export oriented if compare to commodities producing sector and source to decline in growth of trading partner. The service sector played significant role in national competitiveness agenda its due to strong relationship with rest of economy, growth is closely connected with service indirectly linked with human capital. Chenery and Syrquin (1975) examined the relationship between service sector and economic growth using the data of the period 1950 to 1970. They regressed the service sector share of output on per capita income squared and concluded that the relationship was concave to the origin which implied that share of service sector increased with the rise in per capita income but at a decreasing rate. Chenery (1960) by regressing the share of service on per capita income on cross country data, found a positive but an insignificant coefficient and concluded that there was no stable relationship between services and per capita income across countries.

\section{Description of the Variables}

Real Gross Domestic Product: This is an inflation-adjusted measure that reflects the value of all goods and services produced by an economy in a given year, expressed in base-year prices, and is often referred to as "constant price" or "inflation-corrected GDP." This is the endogenous or dependent variable in the model whose behavior is to be explained by a set of explanatory or exogenous variables.

The independent or exogenous or explanatory variables included in the model are:

Educational Services: The educational services sector is part of the education and health services super-sector. The educational service sector comprises establishments that provide instruction and training in a wide variety of subjects. They may also offer food and accommodation services to their students. The provision of qualitative and quantitative educational services to the citizens of a country would make them to be skillful, productive and dynamic. The resultant effect of this on the economy would be an increase in productivity or output. So, this variable is expected to exert a positive influence on economic growth and development. Financial Services: These are economic services provided by the finance industry, which encompasses a broad range of businesses that manage money, including credit unions, banks, credit-card companies, insurance companies, accountancy companies, consumer-finance companies, stock brokerages, investment funds, individual managers and some government sponsored enterprises. The availability, accessibility and affordability of these services to the people of a given country would help in galvanizing economic growth and development. Theoretically, this variable is expected to positively impact on economic growth and development. Real Estate Services: The real estate services relate to the profession of buying, selling or renting land, buildings or housing. The company's operations are conducted through four segments viz: commercial real estate services, residential property management, property improvement services and integrated security services. Economic theory postulates that real estate services should have positive correlation with economic growth in a given economy.

Utilities: Utilities are infrastructure services provided to consumers that are sometimes considered to be "public" services, that is, they are supplied to the public and are important for the normal functioning of the society. Utilities are generally considered to include telecommunications, coal, natural gas, electricity, water and sewage and transportation services. The provision of adequate and qualitative utilities by the government and private sector for the citizens at moderate costs should serve as catalyst for accelerated economic growth. Therefore, the variable should have a positive nexus with economic growth. 
Professional, Scientific and Technical Services: The professional, scientific and technical services industry, as its name implies, is made up of a wide range of businesses that provide clients with professional, scientific and technical services. These services can range from legal services, accounting, tax preparation, bookkeeping, and payroll services, architectural, engineering and related services, specialized design services, computer systems design and related services, management, scientific and technical consulting services, scientific research and development services, advertising and related services. The rendering of qualitative and quantitative professional, scientific and technical services by public and private organizations would go a long way to galvanizing economic growth and development. Thus, this variable is expected to be positively correlated with economic growth.

Human Health and Social Services: Human Health and Social Services is a large and diverse sector that encompasses a wide range of services including hospitals, child care, community health services, social work and care homes for older and disabled people. The healthier the people of a country through the provision of relevant health services by government at various levels, the greater the productivity of the economy would be and vice versa. It is expected that this variable would have a positive nexus with economic growth and development.

Information and Communication Services: This sector is made up of diverse services including software applications and operating systems, web based information and applications such as distance learning; telephones and other telecommunications products; video equipment and multimedia products that may be distributed on videotapes, CDS, DVDS, email, or the world wide web. The availability, accessibility and affordability of these services in an economy would give room for businesses to flourish and thereby enhancing sustainable economic growth. Theoretically, this variable should be positively correlated with economic growth.

Inflation Rate: This refers to persistent increase in the prices of goods and services in the economy. The higher the inflation rate, the higher the prices of services rendered by services industries to people, the lower would be the demand for these services and the slower the rate of economic growth. Thus, this variable is expected to negatively influence economic growth.

Random Variable - This variable considers other independent or explanatory variables influencing services sector contribution to economic growth in Nigeria which are excluded from the model. It takes care of the unexplained part of the model.

\section{Data and Methodology}

The study utilized secondary data which was obtained from the Central Bank of Nigeria Statistical Bulletin of various issues and National Bureau of Statistics. Estimating techniques employed for the study include Augumented Dickey Fuller unit root test, Phillips-Perron unit root test, Johansen Co-integration test and Ordinary Least Square (OLS) regression technique. Real gross domestic product was specified as the dependent variable while education services, financial services, real estate services, utilities, professional, scientific and technical services, information and communication services, human health and social services and inflation rate were the exogenous variables.

\section{Model Specification}

This study investigates the relationship between services sector and economic growth in Nigeria from 1981 to 2017. The mathematical representation of the variables identified from this model is presented as follows:

RGDP $=\mathrm{f}($ EDUCS, FINS, REES, UTS, PSTS, HHSS, IACS, INFR)

where

RGDP $=$ Real Gross Domestic Product

EDUCS $=$ Education Services

FINS $=$ Financial Services

REES $=$ Real Estate Services 
UTS $=$ Utilities Services

PSTS $=$ Professional, Scientific and Technical Services

HHSS $=$ Human Health and Social Services

IACS $=$ Information and Communication Services

$\mathrm{INFR}=$ Inflation Rate

The regression analysis of Ordinary Least Square (OLS), Augumented Dickey Fuller (ADF) unit root test, Phillips-Perron (PP) unit root test and Johansen Cointegration test were employed to examine the impact of services sector on economic growth in Nigeria over the period 1981 to 2017. Specifically, the estimated regression equation is of the following form:

$\mathrm{RGDP}=\mathrm{b}_{0}+\mathrm{b}_{1}$ EDUCS $+\mathrm{b}_{2}$ FINS $+\mathrm{b}_{3}$ REES $+\mathrm{b}_{4}$ UTS $+\mathrm{b}_{5}$ PSTS $+\mathrm{b}_{6}$ HHSS $+\mathrm{b}_{7}$ IACS $+\mathrm{b}_{8}$ INFR $+\mathrm{U}$

$b_{1}, b_{2}, b_{3}, b_{4}, b_{5}, b_{6}, b_{7}$ and $b_{8}$ are the elasticity of the parameters of the respective variables.

\section{Stationarity Test}

In order to ensure that the relationship estimated by the regression among the variables is not a spurious one, the time series data employed need to be stationary. Tables 1 and 2 below show the results of unit root tests carried out on the series. All the variables in the model were subjected to stationary tests of time series data before equation (2) was estimated.

Table 1 AUGUMENTED DICKEY FULLER TEST STATISTICS OF THE VARIABLES

\begin{tabular}{|l|l|l|l|l|c|c|}
\hline $\begin{array}{l}\text { VARIABLE } \\
\text { S }\end{array}$ & $\begin{array}{l}\text { ADF } \\
\text { STATISTIC } \\
\text { S }\end{array}$ & $\begin{array}{l}\text { 1\% } \\
\text { CRITICA } \\
\text { L VALUE }\end{array}$ & $\begin{array}{l}\text { 5\% } \\
\text { CRITICA } \\
\text { L VALUE }\end{array}$ & $\begin{array}{l}\text { 10\% } \\
\text { CRITICA } \\
\text { L VALUE }\end{array}$ & $\begin{array}{l}\text { ORDER OF } \\
\text { INTEGRATIO } \\
\text { N }\end{array}$ & $\begin{array}{l}\text { MAXIMU } \\
\text { M } \\
\text { NUMBER } \\
\text { OF LAG }\end{array}$ \\
\hline EDUCS & -5.135549 & -4.243644 & -3.544284 & -3.204699 & $\mathrm{I}(2)$ & 3 \\
\hline FINS & -7.496437 & -3.632900 & -2.948404 & -2.612814 & $\mathrm{I}(1)$ & 3 \\
\hline INFR & -6.264748 & -3.639407 & -2.951125 & -2.614300 & $\mathrm{I}(1)$ & 3 \\
\hline PSTS & -6.460911 & -3.646342 & -2.954021 & -2.615817 & $\mathrm{I}(2)$ & 3 \\
\hline REES & -6.239212 & -3.639407 & -2.951125 & -2.614300 & $\mathrm{I}(2)$ & 3 \\
\hline RGDP & -6.425054 & -3.639407 & -2.951125 & -2.614300 & $\mathrm{I}(2)$ & 3 \\
\hline UTS & -5.437530 & -3.661661 & -2.960411 & -2.619160 & $\mathrm{I}(2)$ & 3 \\
\hline HHSS & -5.921575 & -3.646342 & -2.954021 & -2.615817 & $\mathrm{I}(2)$ & $\mathrm{I}(2)$ \\
\hline IACS & -6.492092 & -3.639407 & -2.951125 & -2.614300 & & 3 \\
\hline
\end{tabular}

Source: Authors' Computation using E-view 9 version

Table 2 PHILLIPS-PERRON TEST STATISTICS OF THE VARIABLES

\begin{tabular}{|l|l|l|l|l|l|c|}
\hline $\begin{array}{l}\text { VARIABLE } \\
\text { S }\end{array}$ & $\begin{array}{c}\text { PP } \\
\text { STATISTIC } \\
\text { S }\end{array}$ & $\begin{array}{l}\text { 1\% } \% \\
\text { CRITICA } \\
\text { L VALUE }\end{array}$ & $\begin{array}{l}\text { 5\% } \\
\text { CRITICA } \\
\text { L VALUE }\end{array}$ & $\begin{array}{l}\text { 10\% } \\
\text { CRITICA } \\
\text { L VALUE }\end{array}$ & $\begin{array}{l}\text { ORDER OF } \\
\text { INTEGRATIO } \\
\text { N }\end{array}$ & $\begin{array}{l}\text { MAXIMU } \\
\text { M } \\
\text { NUMBER } \\
\text { OF LAG }\end{array}$ \\
\hline EDUCS & -5.323981 & -4.243644 & -3.544284 & -3.204699 & $\mathrm{I}(1)$ & 3 \\
\hline FINS & -11.72762 & -3.632900 & -2.948404 & -2.612874 & $\mathrm{I}(1)$ & 3 \\
\hline INFR & -8.480593 & -3.632900 & -2.948404 & -2.612874 & $\mathrm{I}(1)$ & 3 \\
\hline PSTS & -7.847731 & -3.639407 & -2.951125 & -2.614300 & $\mathrm{I}(2)$ & 3 \\
\hline REES & -6.448012 & -3.639407 & -2.951125 & -2.614300 & $\mathrm{I}(2)$ & 3 \\
\hline RGDP & -6.884731 & -3.639407 & -2.951125 & -2.614300 & $\mathrm{I}(2)$ & 3 \\
\hline UTS & -3.597472 & -2.632688 & -1.950687 & -1.611059 & $\mathrm{I}(1)$ & 3 \\
\hline HHSS & -6.391097 & -3.639407 & -2.951125 & -2.614300 & $\mathrm{I}(1)$ & 3 \\
\hline IACS & -7.150077 & -3.639407 & -2.951125 & -2.614300 & $\mathrm{I}(1)$ & 3 \\
\hline
\end{tabular}

Source: Authors' Computation using E-view 9 version

Unit root tests are conducted for the variables employing Augumented Dickey Fuller (ADF) test and PhillipsPerron (PP) test and the results are presented in the tables $1 \& 2$ above. Note that the Mackinnon (1996) critical values for the Augumented Dickey Fuller test and the Phillips-Perron test estimation at 1\%, 5\% and $10 \%$ 
significance levels are stated in the tables above. Stationary (unit root) tests conducted for the set of variables enumerated above revealed that all the variables are stationary at their various first and second differences.

\section{Table 3}

\section{Johansen Cointegration Test}

Date: 03/17/19 Time: $14: 55$

Sample(adjusted): 19832017

Included observations: 35 after adjusting endpoints

Trend assumption: Linear deterministic trend

Series: RGDP FINS EDUCS REES PSTS UTS HHSS IACS INFR

Lags interval (in first differences): 1 to 1

Unrestricted Cointegration Rank Test

\begin{tabular}{ccccc}
\hline $\begin{array}{c}\text { Hypothesized } \\
\text { No. of CE(s) }\end{array}$ & Eigenvalue & $\begin{array}{c}\text { Trace } \\
\text { Statistic }\end{array}$ & $\begin{array}{c}\text { 5 Percent } \\
\text { Critical Value }\end{array}$ & $\begin{array}{c}\text { 1 Percent } \\
\text { Critical Value }\end{array}$ \\
\hline \hline None $* *$ & 0.988633 & 542.8791 & 192.89 & 204.95 \\
At most 1 ** & 0.957446 & 386.1826 & 156.00 & 168.36 \\
At most 2 ** & 0.915869 & 275.6882 & 124.24 & 133.57 \\
At most 3** & 0.844162 & 189.0499 & 94.15 & 103.18 \\
At most 4 $* *$ & 0.721551 & 123.9870 & 68.52 & 76.07 \\
At most 5** & 0.628324 & 79.23880 & 47.21 & 54.46 \\
At most 6** & 0.431187 & 44.59811 & 29.68 & 35.65 \\
At most 7** & 0.353767 & 24.85101 & 15.41 & 20.04 \\
At most 8** & 0.239237 & 9.570185 & 3.76 & 6.65 \\
\hline \hline
\end{tabular}

$*(* *)$ denotes rejection of the hypothesis at the $5 \%(1 \%)$ level

Trace test indicates 9 cointegrating equation(s) at both $5 \%$ and $1 \%$ levels

\begin{tabular}{ccccc}
\hline \hline $\begin{array}{c}\text { Hypothesized } \\
\text { No. of CE(s) }\end{array}$ & Eigenvalue & $\begin{array}{c}\text { Max-Eigen } \\
\text { Statistic }\end{array}$ & $\begin{array}{c}\text { 5 Percent } \\
\text { Critical Value }\end{array}$ & $\begin{array}{c}\text { 1 Percent } \\
\text { Critical Value }\end{array}$ \\
\hline \hline None $* *$ & 0.988633 & 156.6965 & 57.12 & 62.80 \\
At most 1 $* *$ & 0.957446 & 110.4944 & 51.42 & 57.69 \\
At most 2** & 0.915869 & 86.63833 & 45.28 & 51.57 \\
At most 3** & 0.844162 & 65.06288 & 39.37 & 45.10 \\
At most 4** & 0.721551 & 44.74818 & 33.46 & 38.77 \\
At most 5** & 0.628324 & 34.64069 & 27.07 & 32.24 \\
At most 6 & 0.431187 & 19.74710 & 20.97 & 25.52 \\
At most 7* & 0.353767 & 15.28082 & 14.07 & 18.63 \\
At most 8** & 0.239237 & 9.570185 & 3.76 & 6.65 \\
\hline \hline
\end{tabular}

$*(* *)$ denotes rejection of the hypothesis at the $5 \%(1 \%)$ level

Max-eigenvalue test indicates 6 cointegrating equation(s) at both $5 \%$ and $1 \%$ levels

Table 3 above presents the cointegration result for the variables. It could be observed that the variables in the equation are cointegrated. The presence of cointegration suggests that there is a long-run equilibrium relationship among the variables in the equation. Trace test and Max-eigenvalue test indicate cointegration at the 5\% and 1\% levels of significance respectively. Consequent upon this, an ordinary least square regression was estimated because the variables are stationary at their various first and second differences. 
Table 4

Dependent Variable: RGDP

Method: Least Squares

Date: 03/17/19 Time: 14:49

Sample: 19812017

Included observations: 37

\begin{tabular}{crlrr}
\hline \hline Variable & Coefficient & Std. Error & t-Statistic & Prob. \\
\hline \hline C & 9540.347 & 2462.311 & 3.874550 & 0.0006 \\
FINS & 5.057966 & 1.357729 & 3.725314 & 0.0009 \\
EDUCS & -0.077965 & 11.43148 & -0.006820 & 0.9946 \\
REES & 3.176238 & 2.732140 & 1.162546 & 0.0048 \\
PSTS & 8.179265 & 3.307759 & 2.472751 & 0.0197 \\
UTS & 22.58382 & 8.777049 & 2.573054 & 0.0157 \\
HHSS & -38.71662 & 59.27860 & -0.653130 & 0.5190 \\
IACS & 3.106717 & 0.783014 & 3.967641 & 0.0005 \\
INFR & -1.361684 & 12.91019 & -0.105474 & 0.9168 \\
\hline \hline R-squared & 0.966884 & Mean dependent var & 32749.95 \\
Adjusted R-squared & 0.925994 & S.D. dependent var & 18889.20 \\
S.E. of regression & 1195.574 & Akaike info criterion & 17.21841 \\
Sum squared resid & 40023116 & Schwarz criterion & 17.61026 \\
Log likelihood & -309.5406 & F-statistic & 1119.777 \\
Durbin-Watson stat & 2.233323 & Prob(F-statistic) & 0.000000 \\
\hline \hline
\end{tabular}

Table 5

Presentation of Regression Result

\begin{tabular}{|l|l|l|l|l|l|l|}
\hline Variable & Coefficient & Std. Error & t-Statistic & Probability & $\begin{array}{l}\text { Apriori } \\
\text { Exp }\end{array}$ & Inference \\
\hline Constant & 9540.347 & 2462.311 & 3.874550 & 0.0006 & $\mathrm{~b}_{0}>0$ & $\begin{array}{l}\text { Correct sign and } \\
\text { significant }\end{array}$ \\
\hline FINS & 5.057966 & 1.357729 & 3.725314 & 0.0009 & $\mathrm{~b}_{1}>0$ & $\begin{array}{l}\text { Correct sign and } \\
\text { significant }\end{array}$ \\
\hline EDUCS & -0.077965 & 11.43148 & -0.006820 & 0.9946 & $\mathrm{~b}_{2}<0$ & $\begin{array}{l}\text { Incorrect sign and } \\
\text { insignificant }\end{array}$ \\
\hline REES & 3.176238 & 2.732140 & 1.162546 & 0.2548 & $\mathrm{~b}_{3}>0$ & $\begin{array}{l}\text { Correct sign and } \\
\text { significant }\end{array}$ \\
\hline PSTS & 8.179265 & 3.307759 & 2.472751 & 0.0197 & $\mathrm{~b}_{4}>0$ & $\begin{array}{l}\text { Correct sign and } \\
\text { significant }\end{array}$ \\
\hline UTS & 22.58382 & 8.777049 & 2.573054 & 0.0157 & $\mathrm{~b}_{5}>0$ & $\begin{array}{l}\text { Correct sign and } \\
\text { significant }\end{array}$ \\
\hline HHSS & -38.71662 & 59.27860 & -0.653130 & 0.5190 & $\mathrm{~b}_{6}>0$ & $\begin{array}{l}\text { Incorrect sign and } \\
\text { significant }\end{array}$ \\
\hline IACS & 3.106717 & 0.783014 & 3.967641 & 0.0005 & $\mathrm{~b}_{7}>0$ & $\begin{array}{l}\text { Correct sign and } \\
\text { significant }\end{array}$ \\
\hline INFR & -1.361684 & 12.91019 & -0.105474 & 0.9168 & $\mathrm{~b}_{8}<0$ & $\begin{array}{l}\text { Correct sign and } \\
\text { significant }\end{array}$ \\
\hline
\end{tabular}

\section{Discussion of Empirical Findings}

Table 5 shows that financial services (FINS) affects economic growth (RGDP) positively. FINS coefficient is 5.057966 which means that one naira increase in FINS increases economic growth by 50.57 units. Real estate services (REES), professional, scientific and technical services (PSTS), utilities (UTS) and information and communication services (IACS) all have statistically significant positive relationships with economic growth 
(RGDP) in Nigeria. A one naira increase in REES, PSTS, UTS and IACS would bring about 3.176238, $8.179265,22.58382$ and 3.106717 units rise in economic growth (RGDP) in the Nigerian economy which is in conformity to apriori theoretical economic expectation. On the other hand, education services (EDUCS) and human health and social services (HHSS) exert statistically significant negative relationships with the dependent variable (RGDP) in the model. The coefficients of EDUCS and HHSS are -0.077965 and -38.71662 which implies that one naira escalation in EDUCS and HHSS would reduce economic growth by 7.79 and 38.71 units respectively which contradicts apriori theoretical expectation. Thus, the result of the analysis states that FINS, REES, PSTS, UTS and IACS have positive and significant effects on RGDP while EDUCS and HHSS have negative and significant effects on RGDP.

The coefficient of determination $\left(\mathrm{R}^{2}\right)$ which determines the goodness of fit of the model specifies that the independent variables explained $96 \%$ of the variations observed in the dependent variable. This was moderated by the adjusted $\mathrm{R}$-squared $\left(\mathrm{AR}^{2}\right)$ to $92 \%$, indicating that there are other variables other than the explanatory variables that might likely have an impact on the dependent variable. The value of the F-statistic which is 1111.7 shows that the regression as a whole is significant, meaning that the regressors or explanatory variables in the model (FINS, EDUCS, REES, PSTS, UTS, HHSS IACS and INFR) reliably predict variations in RGDP. Moreover, the p-value (significance) is 0.000000 which also indicates that RGDP is predicted with $100 \%$ probability by the exogenous variables. Therefore, the F-value associated p-value proves that there is significant relationship between the RGDP and the explanatory variables within the Nigerian economy. Given the fact that the coefficients of FINS, REES, PSTS, UTS and IACS are positively signed and the p-values of their t-statistic are less than 0.05 level of significance, we reject the null hypothesis which states that services sector has no statistically significant positive relationship with economic growth in Nigeria.

\section{Conclusion and Recommendations}

This study explored the economic growth implications of services sector in Nigeria over the period 1981 to 2017. Empirical analysis was conducted using the multiple regression of the ordinary least square technique to the annual data on the Nigerian economy for the period 1981 to 2017. The model was found to be significant and most of its parameter estimates conformed to the apriori theoretical expectation. Empirical findings from the study revealed that financial services (FINS), real estate services (REES), utilities (UTS), professional, scientific and technical services (PSTS) and information and communication services (IACS) have statistically significant positive relationships with economic growth (RGDP) while education services (EDUCS) and human health and social services exert statistically significant negative correlation with economic growth (RGDP). Based on the estimated results, the following policy measures are recommended:

-Government at all levels should offer tariff and tax reduction for investment projects in many services subsectors like hotels and restaurants, hospitals, shipping, railways, tourism, telecommunications, distribution and others.

-Public and private policies should be directed towards the adoption of an overall reforming plan where capital and knowledge intensive services should play a prominent role in order to enhance the productivity in the services sector.

-Creation of enabling environment for services sector to thrive by the various tiers of government through the provision of key infrastructural amenities such as uninterrupted power supply, good roads network and regular water supply.

-Higher institutions of learning and private organizations should design and implement innovative programmes capable of enhancing the abilities and know-how of graduates so as to make them employable by the services providers and enhance their productivity.

-Most services' subsectors, and especially distribution services should invest much more heavily in knowledge and information and communication technology within their supply chain in order to accelerate the rate of economic growth. 


\section{References}

Abdulkarim, K. A. (2014). Does Service Sector Cause Economic Growth? Empirical Evidence from Saudi Arabia. Indiana Journal of Global Legal Studies, 7(1), pp.

AFDB et al. (2011). African Economic Outlook (2011). Available online:

https://www.afdb.org/fileadmin/uploads/afdb/documents/Generic-Documents/Media Embargoed Content/EN/-

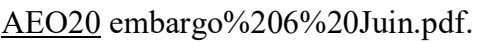

Arnold, J., Javorick, B., Lipscomb, M. \& Mattoo, A. (2010). Services Reform and Manufacturing Performance: Evidence from India. Discussion Paper No. 8011, CEPR.

Baharom, A. H., Muzafar, S. H. \& Royfaizal, R. C. (2009). Testing for Service-led and Investment-led hypothesis: Evidence from 'Chindia'. Asian Social Science, 5(3), pp. 91-98.

Bhorat, H., Steenkamp, F., Rooney, C., Kachingwe, N. \& Lees, A. (2016). Understanding and Characterizing the Services Sector in South Africa: An Overview. WIDER Working Paper 2016/157. Helsinki: UNU-WIDER.

Bosworth, B. \& Maertens, A. (2009). The Role of the Services Sector in Economic Growth and Employment Generation in South Asia. In E. Ghani \& H. Kharas, eds. The Service Revolution in South Asia. Washington DC: World Bank, Chapter 2.

Central Bank of Nigeria Statistical Bulletin, 2017.

Chenery, H. B. (1960). Patterns of Industrial Growth. The American Economic Review, 50, pp. 624-654.

Chenery, H. B. \& Syrquin, M. (1975). Patterns of Development, 1957-1970. London: Oxford University Press. Eichengreen, B. \& Gupta, P. (2013). Two Waves of Services Sector Growth. Oxford Economic Papers, 65, pp. 96-123. doi:10.1093/oep/gp.059.

Ellis, M., McMillan, M. \& Silver, J. (2017). Employment and Productivity Growth in Tanzania's Services Sector (No. 016). World Institute for Development of Economic Research (UNU-WIDER).

Gani, A. \& Clemes, M. D. (2002). Services and Economic Growth in ASEAN Economies. ASEAN Economic Bulletin, 19(2), pp. 155-169.

Ghani, E. (2009). Is Services-led Growth a Miracle for South Asia? In: Ghani, E. \& Kharas, H., eds. The Services Revolution in South Asia. Washington, DC: World Bank, pp. 9-36.

Ghani, E. (ed.) (2010). The Service Revolution in South Asia. New Delhi: Oxford University Press.

Ghani, E. \& O'Connell, S. (2014). Can Service Growth be a Growth Escalator in Low Income Countries? Policy

Research Working Paper 6971. World Bank. Available online: http://hdl.handle.net/10986/19352.

Glasmeier, A. \& Howland, M. (1993). Service-led Rural Development: Definitions, Theories and Empirical

Evidence. International Regional Science Review, 16(1-2), pp. 197-229.

Hoekman, B. \& Eschenbach, F. (2005). Services Policy Reform and Economic Growth in Transition Economies, 1970-2004. Policy Research Working Paper No. 3663. The World Bank.

Kale, (2016). Pushing Nigeria's Economic Diversification Forward: Issues and Options. $7^{\text {th }}$ Stanbic IBTC

Investors' Conference. Available online:

http://www.nigerianstat.gov.ng/resource/opening\%20Address $\% 20$ Stanbic $\% 20$ investment $\% 20$ conference $\% 20201$ 6ko\%20-clean-pdf.

Khanna, A., Papadavid, P., Tyson, J. \& te Velde, D. W. (2016). The Role of Services in Economic Transformation- With an Application to Kenya Supporting Economic Transformation. Available online: http://set.odi.org/wp-content/uploads/2016/02/The-Role-of-Services-in-Economic-Transformation.kenya.pdf. Kongsamut, R., Rebelo, S. \& Xie, D. (2001). Beyond Balanced Growth. The Review of Economic Studies, 68, pp. 869-882.

Madhav, P. D. (2016). Stride of Services Sector in Nepal's Trajectories of Structural Change. European Journal of Development Issues, 21\&22(1-2), pp. 69-98.

Mansell, R. (1985). The Services Sector and Western Economic Growth. Canadian Public Policy, 11(1), pp. 354-360.

Miroudot, S., Savage, J. \& Shephered, B. (2010). Measuring the Cost of International Trade in Services.

Working Paper. GEM-Services $\mathrm{P}_{0}$. Available online: http://gem.sciencespo.fr/content/publications/pdf/Miroudot/Savage/Shepheredcostofservices04102010.pdf.

Mukherjee, A. (2015). Services Sector in India: Trends, Issues and the Way Forward. Eurasian Geography and Economics, 56(6), pp. 635-655. 
Raber, M. \& Faiz, G. (2016). The Growth of the Services Sector in Palestine: The Productivity Challenge. Journal of Innovation Economics and Management, 1(19), pp.

UNCTAD (2015). Economic Development in Africa: Unlocking the Potential of Africa's Services Trade for Growth and Development. Report of United Nations Conference on Trade and Development.

World Bank (2017). Country Overview: Nigeria. Available online:

http://www.worldbank.org/en/country/nigeria/overview.

Wu, Y. (2015). China's Services Sector: The New Engine of Growth. Eurasian Geography and Economics, 56(6), pp. 618-634.

Yusuf, S. (2015). The Brave New World of Service-led Growth. Eurasian Geography and Economics, 56(6), pp. 602-617. 